\title{
A study on the causes for depletion of Kalayat wetland in Haryana province, India and its winter migratory birds' diversity
}

\author{
Tirshem Kumar Kaushik ${ }^{1 *}$, Rohtash Chand Gupta ${ }^{2}$ and Parveen Kumar Vats ${ }^{2}$ \\ ${ }^{1}$ Department of Biology, Govt. Senior Secondary School, Garhi Jattan, Indri, Karnal-132041, Haryana \\ ${ }^{2}$ Department of Zoology, Kurukshetra University, Kurukshetra-136118, Haryana \\ *Corresponding author. E-mail: tarshemkaushik@rediffmail.com
}

Received: May 31, 2016; Revised received: November 28, 2016; Accepted: May 22, 2017

\begin{abstract}
Kalayat wetland is a historical and religious natural lake having direct connection with a sage, writer, namely, "Kapil-Muni" who is revered in the echelons of Hindu thought as a authority of literary predicament and his epical compositions were composed on the moorings of this very wetland. The objective of this research work is to singularly emphasize on the silently ongoing process of depletion of age-old wetland on a very fast rate in Haryana province of India. In the present research work, a total of 57 species of wetland birds belonging to 8 orders and 15 families were recorded. Out of the 57 species of wetland birds, 29 species of birds were winter migratory, 18 species resident and 7 species were Local migratory. The major causes of extinction of this historical lake of immense universal importance includes its renovation and supposedly rejuvenation by constructing cemented brick wall and consequently destroying the age old aquatic plants and animal, purely decimating the trophic structure. In addition, land filling deliberate and subsequent encroachment has spelled havoc with vast sheet of water. Resultantly, migratory birds coming in winter to Kalayat Wetland from far off places like Ladakh, Siberia, Russia and central Asia have stopped coming.
\end{abstract}

Keywords: Avian diversity, Haryana, Kalayat-Sarovar, Migratory birds, Rural Ponds

\section{INTRODUCTION}

Haryana state is a prosperous state, carved out of erstwhile East-Punjab of independent India in Nov. 1966. Haryana State is a predominantly villages packed area having old relics of medieval period juxtaposed with ultra-modern cities like Gurugram and Faridabad nearby Delhi. The villages are having traditional ponds since times immemorial. These ponds are natural examples of water-shed management in context of rainy water. These ponds have served the rural society in several ways including their great utility for recharging the ground water-table which is very crucial for supporting most modern, high tech agriculture practices comparable to the best ones in the world. What is most interesting is, the facultative facility offered by these rural ponds as harbouring spots for the winter visitor migratory wetland birds! An overall view and idea generated over here hints towards the deterioration of these healthy ponds including Kalayat Wetland. A religious town, namely, Kalayat in district Kaithal has got a vast shallow pond which is, perhaps a natural depression and it is filled with rainy water; could be said to be the only natural Lake, which receives variety of migratory birds each year and this information is also available in Vedic literature. However, this natural sarovar of Kalayat has already been silted with sand and only small portion of the lake survives today.
Linked with the sad plight of Kalayat pond, the overall position of the diversity and number of wetland migratory birds is equally very pitiable and deserves consideration for its mapping so as to fully understand the situation. The objective of this research endeavour is to catalogue the domain of wetland migratory birds that arrive every winter in rural ponds of Haryana Province of India. In the present endeavour, the plight and threats being faced simultaneously by rural wetlands and migratory birds in Haryana, India is mirrored by focusing attention on a very historical rural wetland in Kalayat Town in district Kaithal which is some 60 Kms from Kurukshetra University towards west. However, it was eventually discovered that the rural ponds are in extremely bad shape and are fast progressing towards depletion. Extensive work has been done on these very lines in the Department of Zoology, Kurukshetra University, Kurukshetra (Gupta et al. 2009, 2010 a-c; Gupta and Kaushik, 2010a-e; Gupta and Kaushik, 2011a-b; Gupta et al., 2012; Gupta and Kaushik, 2012; Gupta and Kaushik, 2013a-b; Kaushik and Gupta, 2013; Kaushik and Gupta, 2014).

As such, the migratory birds that arrive in Haryana Province in India face a greater risk of depletion in their populations, which in turn, will have devastating effect on their respective populations in their breeding/ home ground. It was also discovered that these migratory wetland birds that visit Haryana Province rural 


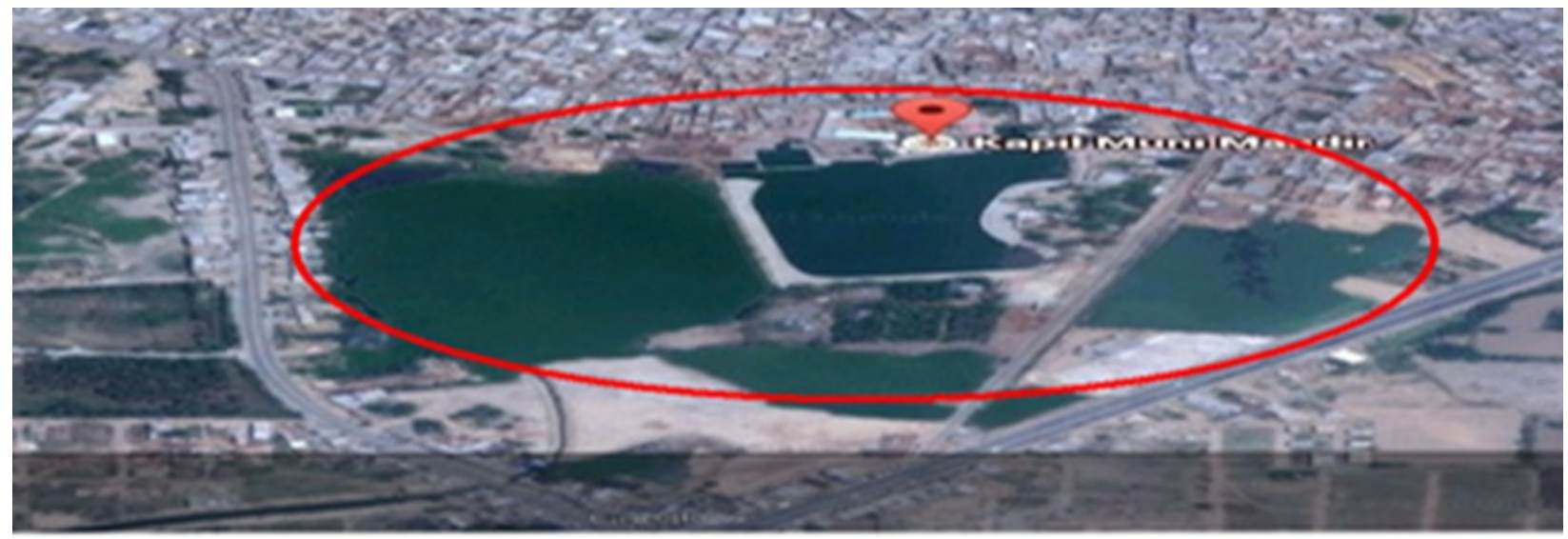

KAPIL MUNI SAROVAR

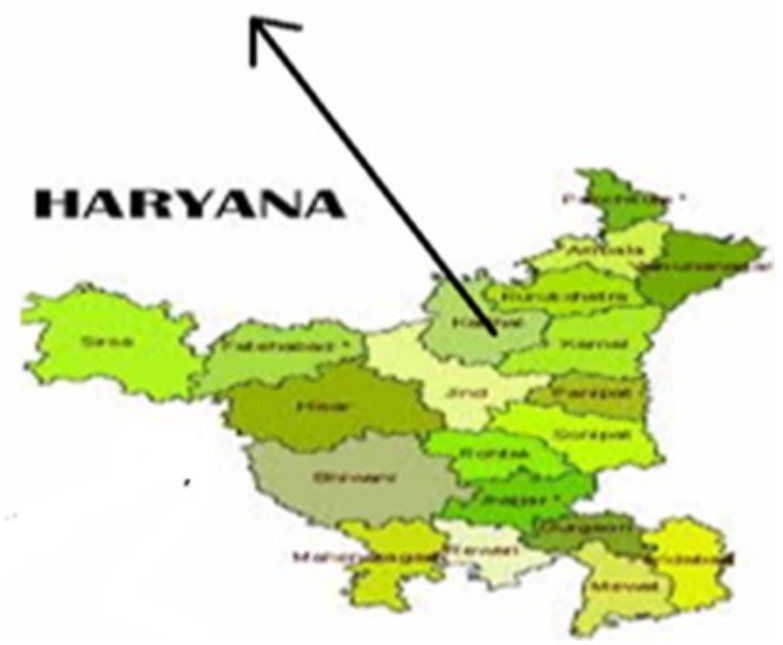

Fig. 1. Map of Kalayat wetland (Kapil Muni Sarovar) in Kaithal district in Haryana province. Source:Wikimapia.org.

wetlands come from far off destinations like Russia, Siberia, China, Tibet and Ladhakh and other transHimalayan ranges under great pressure and facing threats due to poor quality of water, shortage of rooted plants, and profuse proliferation of hyacinth plants in the pond. The present situation become havoc for the migratory birds just like Siberian Crane that used to visit Keoladeo National wetland near Delhi is totally absent nowadays in winters.

\section{MATERIALS AND METHODS}

Study site: Kapil Muni Wetland (2940'25"N $76^{\circ}$ $15^{\prime} 17^{\prime \prime E}$ ) is located in Kalayat town in Kaithal District in Haryana (Fig. 1). It is a historical vast pond having its roots in the Mahabharata times. Kapil Muni Rishi composed Shankhya Darshan (an epic) on the banks of Kalayat Sarovar. The architecture of the Temple-tomb is unique like those of Orissa temples in India. In 1985, it was a vast sarovar spread over $10 \mathrm{Sq}$. Kms or so. The middle portion was deeper upto 10-12 feet. There was rich growth of Selaginella bryopteris, Potamogeton crispus, Chara, Nelumbo nucifera and scores of other rooted, floating and submerged aquatic plants.

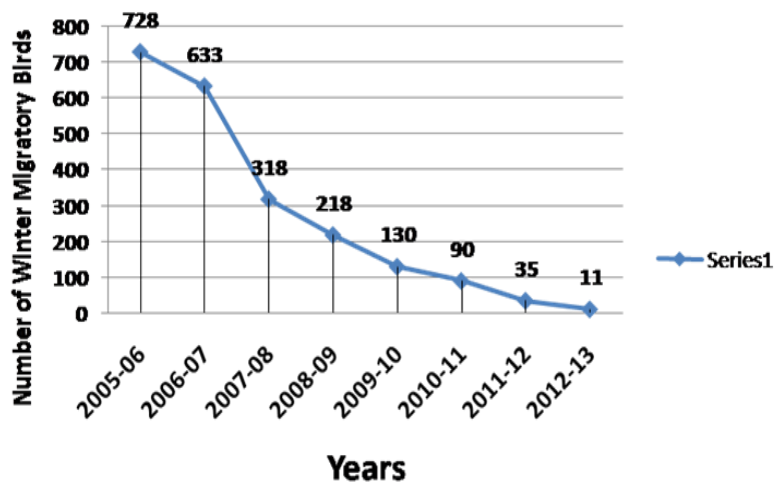

Fig. 2. Reflection of depletion of winter migratory wetland birds at Kalayat wetland in Kaithal district in Haryana province in India between 2005-2013.

There was no growth of Hyacinth in 2000s whatsoever. Blue lilting water with swaying ripples parallel to wind currents was producing soothing environs for the redressal of melancholy moods. In the accompaniment of a heavenly scenario were seen variety migratory birds in plenty where the presence of Mallards was a feather in the personality accentuation effort of the 
Tirshem Kumar Kaushik et al. / J. Appl. \& Nat. Sci. 9 (2): 1194 - 1202 (2017)

Table 1. Checklist of wetland birds of Kalayat Saovar in Kaithal district in Haryana state in northern India.

\begin{tabular}{|c|c|c|c|c|}
\hline S.N. & Scientific Name & Common Name & Res. Status & Observations/Remarks \\
\hline & Podicipediformes & Podicipedidae & & \\
\hline 1 & $\begin{array}{ll}\text { Tachybaptaus } & \text { rufficollis } \\
\text { (Pallas, 1764) } & \end{array}$ & Little Grebe & $\mathrm{R}$ & $\begin{array}{l}\text { Recorded throughout the study period } \\
(2005-2013)\end{array}$ \\
\hline \multirow[t]{2}{*}{2} & $\begin{array}{l}\text { Podiceps } \\
\text { (Linnaeus, } 1758\end{array}$ & Great Crested Grebe & $\mathrm{WM}$ & Recorded during 2005-2008 \\
\hline & Pelecaniformes & Phalacrocoracidae & & \\
\hline 3 & $\begin{array}{l}\text { Phalacrocorax } \\
\text { (Vieillot, 1817) }\end{array}$ & Little Cormorant & $\mathrm{R}$ & $\begin{array}{l}\text { Recorded throughout the study period } \\
(2005-2013)\end{array}$ \\
\hline 4 & $\begin{array}{ll}\text { Phalacrocorax } & \text { fuscicollis } \\
\text { Stephens, } 1826 & \end{array}$ & Indian Shag & LM & $\begin{array}{l}\text { Recorded throughout the study period } \\
(2005-2013)\end{array}$ \\
\hline 5 & $\begin{array}{l}\text { Phalacrocorax } \\
\text { (Linnaeus, 1758) }\end{array}$ & Great Cormorant & $\mathrm{LM}$ & $\begin{array}{l}\text { Recorded throughout the study period } \\
(2005-2013)\end{array}$ \\
\hline \multirow[t]{2}{*}{6} & $\begin{array}{l}\text { Anhingidae } \\
\text { Anhinga melanogaster Pen- } \\
\text { nant, } 1769\end{array}$ & Darter & $\mathrm{R}$ & Recorded during 2005-2008 \\
\hline & Ciconiiformes & Ardeidae & & \\
\hline 7 & $\begin{array}{l}\text { Egretta garzetta (Linnaeus, } \\
1766 \text { ) }\end{array}$ & Little Egret & $\mathrm{WM}$ & $\begin{array}{l}\text { Recorded throughout the study period } \\
(2005-2013)\end{array}$ \\
\hline 8 & $\begin{array}{l}\text { Ardea cinerea Linnaeus, } \\
1758\end{array}$ & Grey Heron & $\mathrm{WM}$ & Recorded during 2005-2008 \\
\hline 9 & Ardea purpurea Linnaeus, & Purple Heron & WM & Recorded during 2005-2008 \\
\hline 10 & $\begin{array}{l}\text { Casmerodius } \\
\text { (Linnaeus 1758) }\end{array}$ & Large Egret & LM & $\begin{array}{l}\text { Recorded throughout the study period } \\
(2005-2013)\end{array}$ \\
\hline 11 & Mesophoyx & Median Egret & $\mathrm{R}$ & Recorded throughout the study period \\
\hline 12 & $\begin{array}{l}\text { Bubulcus ibis (Linnaeus, } \\
1758)\end{array}$ & Cattle Egret & $\mathrm{R}$ & $\begin{array}{l}\text { Recorded throughout the study period } \\
(2005-2013)\end{array}$ \\
\hline 13 & Ardeola grayii (Sykes, & Indian Pond-Heron & $\mathrm{R}$ & Recorded throughout the study period \\
\hline 14 & $\begin{array}{l}\text { Nycticorax } \\
\text { (Linnaeus, 1758) }\end{array}$ & $\begin{array}{l}\text { Black-crowned } \\
\text { Night Heron }\end{array}$ & $\mathrm{R}$ & Recorded during 2005-2008 \\
\hline \multirow[t]{2}{*}{15} & $\begin{array}{l}\text { Ixobrychus cinnamomeus } \\
\text { ( Gmelin,1789) }\end{array}$ & Cinnamon Bittern & $\mathrm{WM}$ & Recorded during 2005-2008 \\
\hline & Ciconiidae & & & \\
\hline 16 & $\begin{array}{l}\text { Mycteria leucocephala } \\
\text { (Pennant, 1769) }\end{array}$ & Painted stork & LM & Recorded during 2005-2008 \\
\hline 17 & $\begin{array}{l}\text { Ciconia } \\
\text { (Boddaert, 1783) }\end{array}$ & White-necked Stork & LM & Recorded during 2005-2008 \\
\hline 18 & $\begin{array}{ll}\text { Anastomus } & \text { oscitans } \\
\text { ( Boddaert, 1783) }\end{array}$ & $\begin{array}{l}\text { Asian Open-bill } \\
\text { Stork }\end{array}$ & LM & Recorded during 2005-2008 \\
\hline 19 & $\begin{array}{l}\text { Threskiornithidae } \\
\text { Threskiornis melanocepha- } \\
\text { lus (Latham,1790) }\end{array}$ & Oriental White Ibis & $\mathrm{LM}$ & Recorded during 2005-2008 \\
\hline 20 & $\begin{array}{l}\text { Pseudibis papillosa } \\
\text { (Temminck, 1824) }\end{array}$ & Black Ibis & $\mathrm{R}$ & Recorded during 2005-2008 \\
\hline 21 & $\begin{array}{l}\text { Platalea leucorodia } \\
\text { (Linnaeus,1758) }\end{array}$ & Eurasian Spoonbill & WM & Recorded during 2005-2008 \\
\hline 22 & $\begin{array}{l}\text { Anseriformes } \\
\text { Dendrocygna }\end{array}$ & $\begin{array}{l}\text { Anatidae } \\
\text { Lesser-whistling }\end{array}$ & SM & Recorded during 2005-2008 \\
\hline 23 & $\begin{array}{l}\text { Anser anser (Linnaeus, } \\
1758)\end{array}$ & Greylag Goose & WM & Recorded during 2005-2008 \\
\hline 24 & $\begin{array}{l}\text { Anser } \\
\text { (Latham,1790) }\end{array}$ & Bar-headed Goose & WM & Recorded during 2005-2008 \\
\hline
\end{tabular}


Tirshem Kumar Kaushik et al. / J. Appl. \& Nat. Sci. 9 (2): 1194 - 1202 (2017)

\begin{tabular}{|c|c|c|c|c|}
\hline 25 & $\begin{array}{l}\text { Anas platyrhynchos Linnae- } \\
\text { us, } 1758\end{array}$ & Mallard & WM & Recorded during 2005-2008 \\
\hline 26 & $\begin{array}{l}\text { Anas strepera Linnaeus, } \\
1758\end{array}$ & Gadwall & WM & Recorded during 2005-2008 \\
\hline 27 & $\begin{array}{l}\text { Anas penelope Linnaeus, } \\
1758\end{array}$ & Eurasian Wigeon & WM & Recorded during 2005-2008 \\
\hline 28 & $\begin{array}{l}\text { Anas poecilorhyncha J.R. } \\
\text { Forester, } 1781\end{array}$ & Spot-billed Duck & WM & $\begin{array}{l}\text { Recorded throughout the study peri- } \\
\text { od (2005-2013) }\end{array}$ \\
\hline 29 & $\begin{array}{l}\text { Anas clypeata Linnaeus, } \\
1758\end{array}$ & Northern Shoveller & WM & $\begin{array}{l}\text { Recorded throughout the study peri- } \\
\text { od (2005-2013) }\end{array}$ \\
\hline 30 & Anas acuta Linnaeus, 1758 & Northern Pintail & WM & $\begin{array}{l}\text { Recorded throughout the study peri- } \\
\text { od (2005-2013) }\end{array}$ \\
\hline 31 & $\begin{array}{l}\text { Anas querquedula Linnae- } \\
\text { us, } 1758\end{array}$ & Garganey & WM & Recorded during 2005-2008 \\
\hline 32 & $\begin{array}{l}\text { Anas crecca Linnaeus, } \\
1758\end{array}$ & Common Teal & WM & $\begin{array}{l}\text { Recorded throughout the study peri- } \\
\text { od (2005-2013) }\end{array}$ \\
\hline 33 & $\begin{array}{l}\text { Aythya ferina (Linnaeus, } \\
1758 \text { ) }\end{array}$ & Common Pochard & WM & Recorded during 2005-2008 \\
\hline \multirow[t]{2}{*}{34} & $\begin{array}{ll}\text { Sarkidiornis } & \text { melanotos } \\
\text { (Pennant, 1769) } & \end{array}$ & Comb Duck & SM & $\begin{array}{l}\text { Recorded throughout the study peri- } \\
\text { od (2005-2013) }\end{array}$ \\
\hline & Gruiformes & Rallidae & & \\
\hline 35 & $\begin{array}{l}\text { Amaurornis phoenicurus } \\
\text { (Pennant, 1769) }\end{array}$ & $\begin{array}{l}\text { White-breasted } \\
\text { Waterhen }\end{array}$ & $\mathrm{R}$ & $\begin{array}{l}\text { Recorded throughout the study peri- } \\
\text { od (2005-2013) }\end{array}$ \\
\hline 36 & $\begin{array}{l}\text { Porphyrio porphyrio } \\
\text { (Linnaeus, 1758) }\end{array}$ & Purple Moorhen & $\mathrm{R}$ & $\begin{array}{l}\text { Recorded throughout the study peri- } \\
\text { od (2005-2013) }\end{array}$ \\
\hline 37 & $\begin{array}{l}\text { Gallinula chloropus } \\
\text { (Linnaeus, 1758) }\end{array}$ & Common Moorhen & WM & $\begin{array}{l}\text { Recorded throughout the study peri- } \\
\text { od (2005-2013) }\end{array}$ \\
\hline 38 & Fulica atra Linnaeus, 1758 & Common Coot & WM & $\begin{array}{l}\text { Recorded throughout the study peri- } \\
\text { od (2005-2013) }\end{array}$ \\
\hline 39 & $\begin{array}{l}\text { Charadriiformes } \\
\text { Hydrophasianus chirurgus } \\
\text { (Scopoli, 1786) }\end{array}$ & $\begin{array}{l}\text { Jacanidae } \\
\text { Pheasant-tailed } \\
\text { Jacana }\end{array}$ & SM & Recorded during 2005-2008 \\
\hline 40 & $\begin{array}{ll}\text { Metopidius } & \text { indicus } \\
\text { (Latham, 1790) }\end{array}$ & $\begin{array}{l}\text { Bronze-winged } \\
\text { Jacana }\end{array}$ & $\mathrm{R}$ & Recorded during 2005-2008 \\
\hline 41 & $\begin{array}{l}\text { Charadriidae } \\
\text { Charadrius dubius Sco- } \\
\text { poli,1786 }\end{array}$ & Little Ringed Plover & WM & $\begin{array}{l}\text { Recorded throughout the study peri- } \\
\text { od (2005-2013) }\end{array}$ \\
\hline 42 & $\begin{array}{l}\text { Charadrius alexandrinus } \\
\text { Linnaeus, } 1758\end{array}$ & Kentish Plover & WM & Recorded during 2005-2008 \\
\hline 43 & $\begin{array}{l}\text { Vanellus malabaricus } \\
\text { (Boddaert, 1783) }\end{array}$ & $\begin{array}{l}\text { Yellow-wattled } \\
\text { Lapwing }\end{array}$ & $\mathrm{R}$ & Recorded during 2005-2008 \\
\hline 44 & $\begin{array}{l}\text { Vanellus indicus (Boddaert, } \\
1783 \text { ) }\end{array}$ & $\begin{array}{l}\text { Red-wattled Lap- } \\
\text { wing }\end{array}$ & $\mathrm{R}$ & $\begin{array}{l}\text { Recorded throughout the study peri- } \\
\text { od (2005-2013) }\end{array}$ \\
\hline 45 & $\begin{array}{l}\text { Vanellus leucurus } \\
\text { (Lichtenstein, 1823) }\end{array}$ & $\begin{array}{l}\text { White-tailed Lap- } \\
\text { wing }\end{array}$ & WM & Recorded during 2005-2008 \\
\hline 46 & $\begin{array}{l}\text { Scolopacidae } \\
\text { Tringa erythropus (Pallas, } \\
\text { 1764) }\end{array}$ & Spotted Redshank & WM & Recorded during 2005-2008 \\
\hline 47 & $\begin{array}{l}\text { Tringa totanus (Linnaeus, } \\
1758 \text { ) }\end{array}$ & Common Redshank & WM & $\begin{array}{l}\text { Recorded throughout the study peri- } \\
\text { od (2005-2013) }\end{array}$ \\
\hline 48 & $\begin{array}{l}\text { Actitis hypoleucos Linnae- } \\
\text { us, } 1758\end{array}$ & Common Sandpiper & WM & $\begin{array}{l}\text { Recorded throughout the study peri- } \\
\text { od (2005-2013) }\end{array}$ \\
\hline 49 & $\begin{array}{l}\text { Tringa } \\
\text { (Gunner,1767) }\end{array}$ & $\begin{array}{l}\text { Common } \\
\text { shank }\end{array}$ & WM & Recorded during 2005-2008 \\
\hline
\end{tabular}


Tirshem Kumar Kaushik et al. / J. Appl. \& Nat. Sci. 9 (2): 1194 - 1202 (2017)

\begin{tabular}{|c|c|c|c|c|}
\hline 50 & $\begin{array}{l}\text { Tringa } \\
\text { (Bechstein,1803) }\end{array}$ & stagnatilis & Marsh Sandpiper & $\bar{W}$ \\
\hline 51 & $\begin{array}{l}\text { Tringa glareola } \\
\text { us, } 1758\end{array}$ & Linnae- & Wood Sandpiper & $\mathrm{W}$ \\
\hline 52 & $\begin{array}{l}\text { Recurvirostridae } \\
\text { Himantopus } \\
\text { (Linnaeus, 1758) }\end{array}$ & himantopus & Black-winged Stilt & $\mathrm{R}$ \\
\hline \multirow[t]{2}{*}{53} & $\begin{array}{l}\text { Recurivirostra } \\
\text { Linnaeus, } 1758\end{array}$ & avosetta & Pied Avocet & , \\
\hline & Laridae & & & \\
\hline \multirow[t]{2}{*}{54} & $\begin{array}{l}\text { Sterna aurantia } \\
1831\end{array}$ & J.E.Gray, & River Tern & $\mathrm{R}$ \\
\hline & Falconiformes & & Accipitridae & \\
\hline \multirow[t]{2}{*}{55} & $\begin{array}{l}\text { Haliastur } \\
\text { (Boddaert,1783) }\end{array}$ & indus & Brahminy Kite & $\mathrm{R}$ \\
\hline & Coraciiformes & & Alcedinidae & \\
\hline 56 & $\begin{array}{l}\text { Ceryle rudis } \\
1758)\end{array}$ & (Linnaeus, & $\begin{array}{l}\text { Lesser Pied King- } \\
\text { fisher }\end{array}$ & $\mathrm{R}$ \\
\hline 57 & $\begin{array}{l}\text { Halcyon } \\
\text { (Linnaeus, 1758) }\end{array}$ & smyenensis & $\begin{array}{l}\text { White-breasted } \\
\text { Kingfisher }\end{array}$ & $\mathrm{R}$ \\
\hline
\end{tabular}

Kalayat Sarovar. The present studies have been inspired by these virtues to pin-point the present position.

Methodology: The crux of the methodology used encompasses periodical visits to Kalayat wetland during October to March in every winter season during the study period. The present work has its past link with period subsequent to 1985 onwards. These observations spanning over 27 years or so reveal the stepwise deterioration of this historic pond alongside its rich diversity of winter migratory birds. Periodical surveys/ visits were made between 2005-08. Some additional visits have been made virtually every winter between 2009-2012. Intensive photography was done to record the successive alteration of the pond. Side by Side, winter migratory birds have been computed in the present studies. The condition of pond/sarovar has been observed and analyzed in the course of successive year's w. e. f. 1985-2012. The deterioration suffered by the pond under investigation has been determined over the years with immense photographic evidence collected through the years. The migratory birds that arrive in the Kalayat Sarovar in each winter have been under the close focus. The methodology followed is based on Ali (1996), Kumar et al. (2005), Gupta et al. (2010a-c), Gupta and Kaushik (2010a-e) and Gupta and Kaushik (2011). The wetland birds observed during the study period were further segregated according to their residential status categories like: Resident (R); "Winter Migratory (WM)"; "Local Migratory (LM)" and Summer Migratory (SM) by following the technique developed by Kumar et al, 2005. The pond was surveyed in its entirety on foot. The cameras used were (i) Zenith 1986 Model with tele-lens and (ii) Nikon Coolpix P500. The Identification of birds was done following the reference books (Ali, 1996; Ali and Rip-

ley, 1987; Grimmet et al., 1998 and Kumar et al., 2005). The nomenclature follows Manakadan and Pittie (2001).

\section{RESULTS AND DISCUSSION}

The present research work was carried out during 2005 -2012 for the observation of winter migratory birds along with their wintering ground which act as winter sojourns for the migratory birds. An issue has come to the fore in consequence of the present studies regarding the ever fast degradation of rural ponds pausing threats to the very existence of several winter migratory wetland birds having connection with their respective home breeding grounds far away from the frontiers of India, including countries like Tibet, Siberia, Russia, China and trans-Himalayan places including our own Ladakh.

The fact of the matter is that to begin with, we have focusing our attention on cataloguing the diversity of winter migratory birds in Kalayat wetland in Haryana province of Northern Haryana. In all, 57 species of wetland birds belonging to 8 orders and 15 families were observed from the Kalayat sarovar in Kaithal district in Haryana (Table-1, Fig. 2 and Plate-2). Out of the 57 wetland birds, 29 species of birds were winter migratory, 18 species resident, 7 species Local migratory and three species of birds like Comb Duck Sarkidiornis melanotos, Lesser-whistling Duck Dendrocygna javanica and Pheasant tailed Jacana Hydrophasianus chirurgus were summer migratory (Table-1).

It is evident from Table 1 that during 2005-08, a rich diversity of birds used to arrive in the water sheet of Kapil Muni-sarovar. To mention few of these, birds like Eurasian Wigeon Anas penelope, Garganey Anas querquedula, Northern Pintail Anas acuta, Northern 

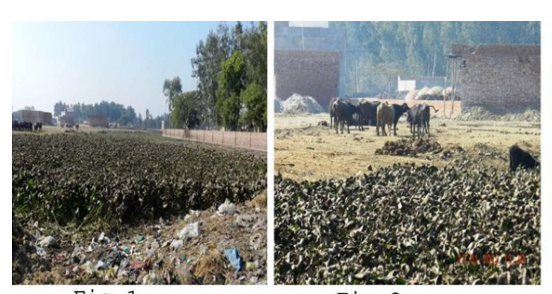

$\mathrm{Fig.2}$

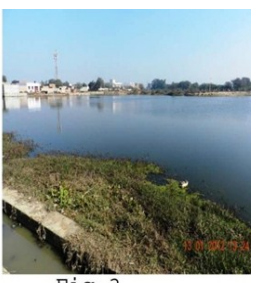

Fig.3

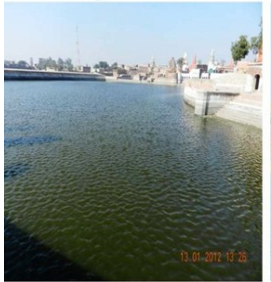

Fig. 4

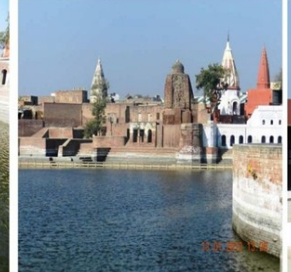

Fig.5

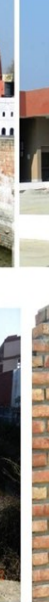

Fig. 8
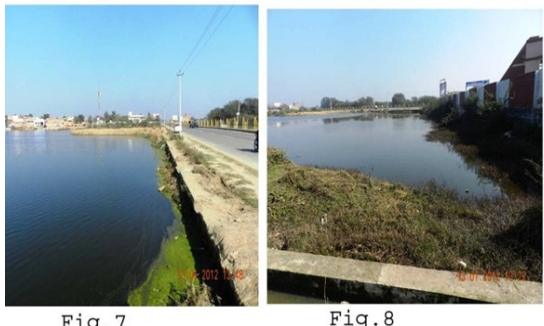

Fig. 7

Plate 1. Pictorial illustration of scenario of prevalent conditions at Kalayat sarovar in Kaithal district in Haryana during 2005-2012. Figs. 1-2.: Showing huge proliferation of Hyacinth plants in the sarovar, Figs. 3-4, 7-8.: Showing the condition of water sheet of sarovar during 2005-2008, Fig. 5: Renovated Kapil Muni Sarovar, Fig. 6: Showing Bus Stand of Kalayat made within the Kalayat Sarovar, Fig. 9: Renovation stone of Kapil Muni Sarovar.

Shoveller Anas clypeata, Common Teal Anas crecca, Mallard Anas platyrhynchos, Common Pochards Aythya ferina, Great Crested Grebe Podiceps cristatus, Cinnamon Bittern Ixobrychus cinnamomeus, Eurasian Spoonbill Platalea leucorodia, Spot-billed Duck Anas poecilorhyncha, Bar-headed Goose Anser indicus, Greylag Goose Anser anser, Gadwall Anas strepera, Little-ringed Plover Charadrius dubius, Kentish Plover Charadrius alexandrinus, White-tailed Lapwing Vanellus leucurus, Spotted Redshank Tringa erythropus, Common Redshank Tringa totanus, Common Sandpiper Actitis hypoleucos, Common Greenshank Tringa nebularia, Marsh Sandpiper Tringa stagnatilis, Wood Sandpiper Tringa glareola and Pied Avocet Recurivirostra avosetta used to found in Kalayat Sarovar in each winter. At the same time, birds like Painted Stork Mycteria leucocephala, Open-billed Stork Anastomus oscitans, White-necked Stork Ciconia episcopus, Oriental White Ibis Threskiornis melanocephalus and Black Ibis Pseudibis papillosa were also observed from this holy sarovar.

However, the crucial revelation seeks to point out that wetland birds like Painted Stork, Oriental White Ibis, Comb Duck, Darter Anhinga melanogaster, Eurasian Spoonbill, Black Ibis and Yellow-wattled Lapwing Vanellus malabaricus do invoke concern at global level since these have been labeled as threatened birds by IUCN, CITES and Wildlife (Protection) Act, 1972. Painted Stork and Oriental white Ibis are Near Threatened as per IUCN Red Data list (Birdlife International, 2001)

At global level as per CITES standards, Comb Duck and Eurasian Spoonbill are listed in appendix II of CITES and have been spotted at Kalayat Sarovar. According to our own Wildlife (Protection) Act, 1972, all winter migratory wetland birds fall in schedule IV except Eurasian Spoonbill which is listed in Schedule I of Wildlife (Protection) Act, 1972. Gupta et al. (2012) reported 46 species of wetland birds from Surajkund sarovar in Amin village in Kurukshetra district. At the same time, Gupta and Kaushik (2012) observed 64 species of wetland birds from Raipur village pond in Karnal district in Haryana. It is crucial to mention that both Surajpur Sarovar and Raipur village pond once acts as heaven for the migratory birds but today these ponds are converted into commercial fish pond so that migratory birds not seen in these ponds.

It is pertinent to mention that birds like Bar-headed Goose which come to India by overflying the Mount Everest are no more available. Birds coming from Siberia include amongst others Common Greenshank, Spotted Redshank, Common Pochard, Marsh Sandpiper, Wood Sandpiper and Glossy Ibisare no more seen from this area (Table-1). Birds like Bar-headed Goose and Garganey coming from Tibet are not observed these days. At the same time, migratory birds like Gadwall, Northern Shoveller, Northern Pintail, Common Teal and Red-crested Pochard Rhodonessa rufina coming from Russia overflying snow clad peaks of Himalayas are no more seen. Most of these birds were seen regularly in every winter season in Kalayat till 2008.

It is very important to recall the migratory effort in-put by these birds by way of journeying for thousands of kilometers. It is important to gauze the evolutionary effort in put through millennia, epochs and eras, It is also important to mention that the stunning decrease in the diversity of these winter migratory wetland birds were observed in Kalayat-Sarovar between 2008-12. Birds like Mallard, Garganey, Eurasian Wigeon, Great -crested Grebe, Common Pochard, Greylag Goose have stopped altogether arriving in winter in Kalayat sarovar. Simultaneously, it is pertinent to mention that during 2005s-2008s where good position of the KapilMuni Sarovar is demonstrated by groups of birds, vast sheet of water and variety of supporting aquatic plants necessary for birds for food and for the purification of water (Lotus, Chara, Salagenella, and Reeds etc) and with no hyacinth. Compared to this, it is crucial to view the condition of the pond in today's time. Today most of the water sheet has given way to land filling and encroachment by certain scrupulous entity (Plate1). Over and above, the Govt. of Haryana has also 
Tirshem Kumar Kaushik et al. / J. Appl. \& Nat. Sci. 9 (2): 1194 - 1202 (2017)

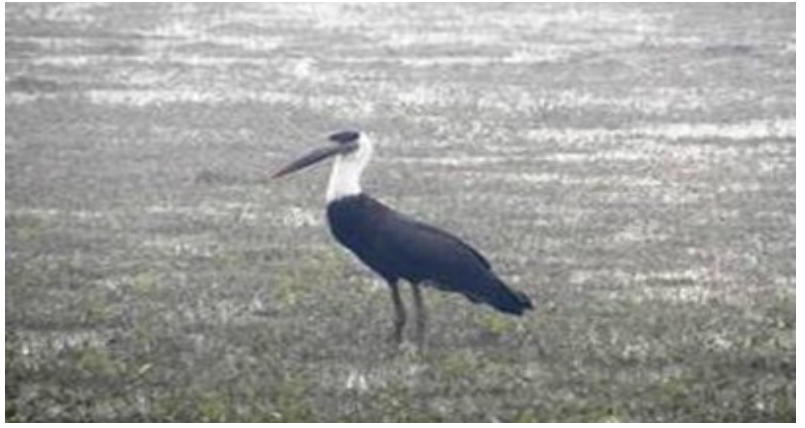

Fig.1. White necked Stork

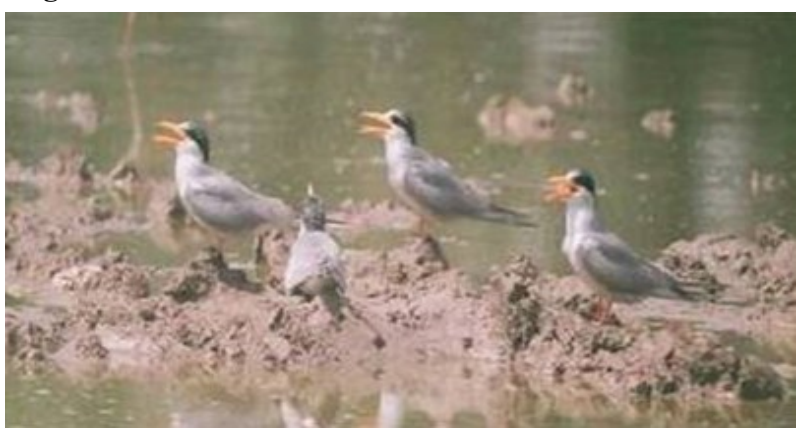

Fig.3. River Terns

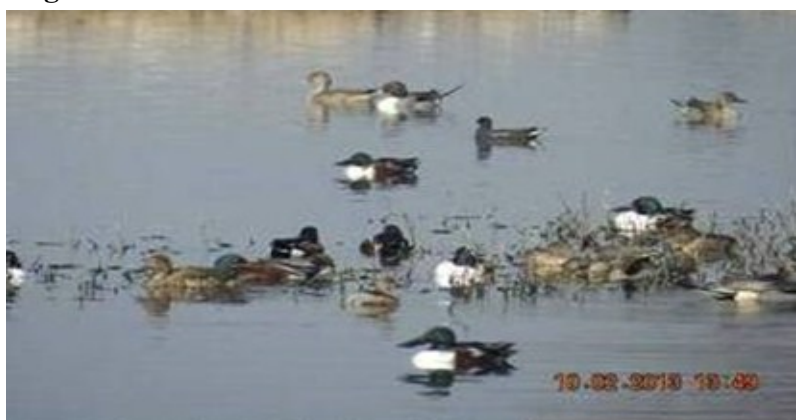

Fig.5. A mixed flock of Northern Shovellers, Northern Pintails, Little Grebe and Common Teal

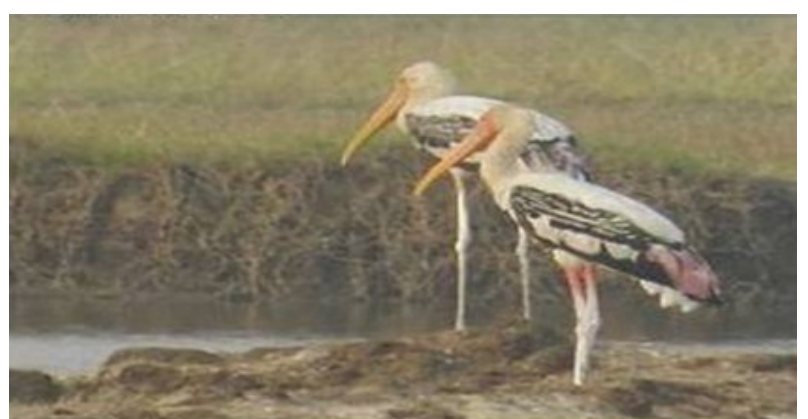

Fig.7. Painted Storks

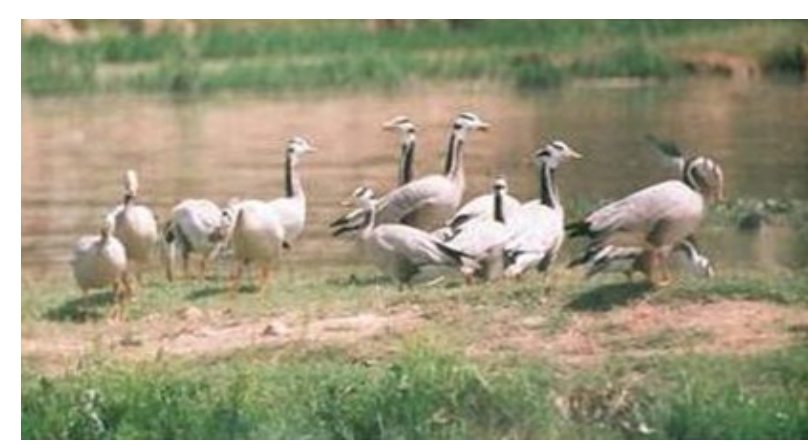

Fig.2. A small flock of Bar-headed Geese

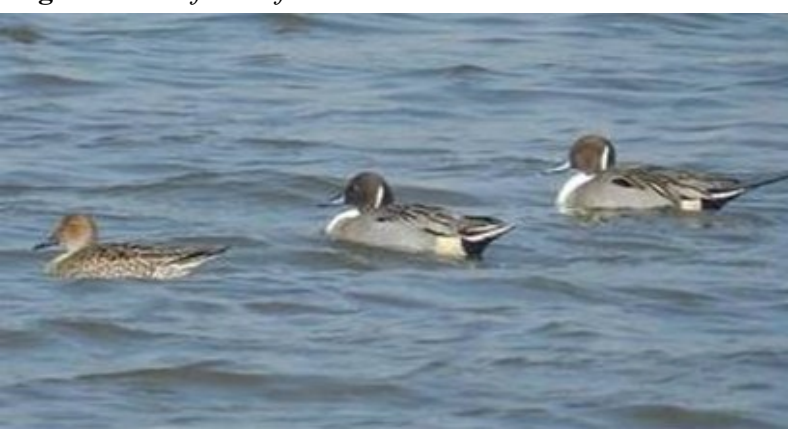

Fig.4. Northern Pintails

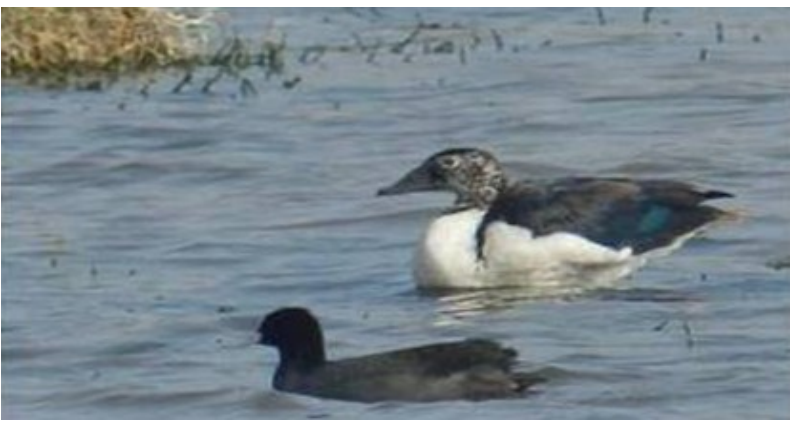

Fig.6. Comb Duck and Common Coot

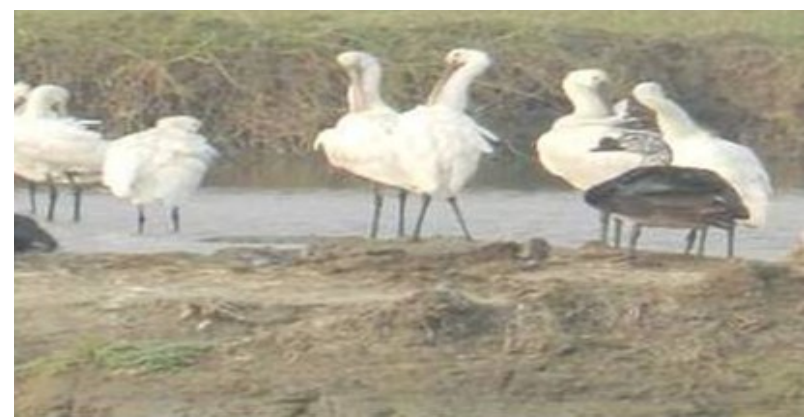

Fig.8. Eurasian Spoonbills and Comb Duck

Plate 2. Wetland birds observed from Kalayat wetland in Haryana Province in India during 2005-2012.

added fuel to fire by constructing a Bus Stand in the very deep past of sarovar (Plate-1). The Govt. has further spoiled the sarovar by constructing a 50-75 wide road right in the peripheral margins of the sarovar (Plate-1). Renovation of the original sarovar by the Govt. has spilled the habitat capacity of sarovar by constructing concrete high rising walls on all its four sides by turning it into a "Corridoored-Sarovar" unfit for migratory birds by not providing moorings' space for squatting alongside total absence of wetland plants and hence no food (Plate-1). The fish stock of the pond is large sized and it cannot be taken by ordinary birds. There is no lotus plants, no Chara, no Salagenella etc and hence water has been rendered into a cold poisonous soup. A Market and several houses have been constructed. As of today the sarovar stands depleted, de- 
stroyed and eutropied. It is one example to demonstrate the plight and threats being faced simultaneously by wetlands and migratory birds in Haryana, elsewhere also. The situation is similar in virtually in all the adjoining states including Punjab, Uttar Pradesh, Madhya Pradesh, Uttarakhand and in some parts of Rajasthan in India.

The point is strengthened by quoting the case of Keoladeo National Park and Siberian Crane Grus leucogeranus. During 1960s, rich groups of Siberian Crane used to be seen and their gradually declined to Zero in 2003 related with graded degradation of several societal and ecological habitat destruction. If one serious cause of Siberian Cranes' disaster in Keoladeo National Park was put up as "Head-Lines" by National Dailies, then birds like Mallards, Bar-headed Goose, Common Pochard, Tufted Pochard, Spot-billed Duck, Red-crested Pochard, Common Teal, Lesser-whistling Teal, Garganey, Gadwall, Wigeon, Northern Pintail, Northern Shoveller, Common Redshank, Spotted Redshank, Greylag Goose etc may disappear unsung, unheard, unseen in a pin drop silence in entire northern India. Let us join in a practical way to restore the traditional rural "sarovars" which serve as wintering grounds for the aforesaid precious global wealth of winter migratory birds. The entire phenomenon has been demonstrated herein by discussing the "KAPILMUNI- SAROVAR" in District Kaithal in Haryana. This episode can be safely extrapolated to thousands of rural sarovars in northern India including Punjab, Jammu and Kashmir, Uttarakhand, Uttar Pradesh, Madhya Pradesh, Rajasthan, Bihar, West Bengal and Orissa etc. Let us "SAVE-POND TO SAVE WETLAND BIRDS" of all hues.

\section{Conclusion}

Precisely speaking, virtually the entire, once upon a time a healthy pond, reverberating with deep blue waters is dead today. It is real ground situation verifying the plight of all other wetland big and small. The situation is grave and serious. The land filing process gained momentum in early 2005 and is in intense capacity even as of now. Land filing of this historic pond has been indulged in by Govt. Departments as well as by the certain scrupulous entity. Govt. of Haryana has indented the pond by creating an ultra modern General Bus Stand (Kalayat) Haryana, India alongside by making a permanent walled structure on all the sides of the pond. The latter step prompted the local Land-Mafia to proceed forward on a very hopeless mission of encroaching the pond on all its sides. The land filled area is now a New-residential colony. It must be taken cognizance of by Govt. otherwise the damage done to winter migratory birds in India will be visible even in the original home breeding grounds of the respective birds. Many of the birds are on their journey of fate meted out to Siberian Crane in Keoladeo National Park in
India. The situation described in reference of Kalayat sarovar can be safely extrapolated to all other ponds in Haryana. Above all, this situation can be extrapolated in context of Punjab, Uttarakhand, Uttar Pradesh, Rajasthan, Delhi etc. It will be no good to protect the environment in discussions over the Television, Seminars, and conferences and at international platforms. Let us rise to the occasion.

\section{ACKNOWLEDGEMENTS}

The authors are thankful to authorities of Kurukshetra University including Chairman, Department of Zoology, Kurukshetra University, Kurukshetra for cooperation, encouragement and inspiration

\section{REFERENCES}

Ali, S. (1996). The Book of Indian Birds. 12 $2^{\text {th }}$ Edition (Revised and enlarged): Oxford University Press, Mumbai.

Ali, S. and Ripley, S. D. (1987). Handbook of the birds of India and Pakistan together with those of Bangladesh, Nepal, Bhutan and Sri Lanka.1-10 Vols. Oxford University Press, New Delhi.

Birdlife International (2001). Threatened Birds of Asia: The Birdlife International Red Data Book. Birdlife International, Cambridge, U.K. 246 PP.

Grimmet, R., Inskipp, T. and Inskipp, C. (1998). Birds of the Indian subcontinent. Oxford University Press, Delhi: $888 \mathrm{Pp}$

Kaushik, T. K. and Gupta, R. C. (2013). Understanding and analysing the coordinates of diversity of wetland birds of Asan Barrage near Paonta Sahib, Northern India. Our Nature, 11(2): 192-200

Kaushik, T. K. and Gupta, R. C. (2014). Black Kite populations are suffering declining trends in Kurukshetra and likely to get further depleted-An Analysis Of Causes. Journal of Tropical Life Sciences, 4(1): 14-18

Gupta, R. C. and Kaushik,T. K. (2013a). Discussing implications of Fast Depleting Rural Ponds on the Globally Threatened Wetland winter migratory bird in Haryana: A Case Study of Nigdu Village Pond in District Karnal. Journal of Tropical Life Sciences, 3 (2): 1-9

Gupta, R. C. and Kaushik, T. K. (2013b). Rich winter migratory birds in thousands have become victim of $\mathrm{Ku}-$ rukshetra Utsav in Haryana, India. International Journal of life sciences, 7(1):6-11

Gupta, R. C. and Kaushik, T. K. (2010a). Determination of the domain of spectrum concerning diversity of endangered winter visitor wetland birds in Haryana. Journal of Experimental Zoology, India, 13 (2): 349-354

Gupta, R. C. and Kaushik, T. K. (2010b). Computation of wetland birds in rural areas of Kurukshetra, Haryana, India. Journal of Nature Conservation, 22 (1): 1-11

Gupta, R. C. and Kaushik, T. K. (2010c). On the causative factors responsible for the pathetic plight of Yellow wattled Lapwing in Kurukshetra suburbs. Journal of Nature Conservation, 22 (2): 181-187

Gupta, R. C., Kaushik, T. K. and Gupta, P. K. (2012). Winter Migratory Wetland Birds in Haryana Are Confronting Adverse Conditions in Rural Ponds Resulting in Reduction in Arrival Number: A Case Study of Village 
Amin in Thanesar Block in Kurukshetra District. Indian Journal of Fundamental and Applied Life Sciences, 2 (1):1-7

Gupta, R. C. and Kaushik, T. K. (2012). A case study: to demonstrate total destruction of a vibrant rural pond: hub for over hundred winter migratory birds up to 2005 AD. Life Science Leaflets, 4: 1-11

Gupta, R. C. and Kaushik, T. K. (2010d). Determination of spectrum of winter migratory birds in Yamunanagar district in Haryana (India). Environment Conservation Journal, 11(3): 37-43

Gupta, R. C. and Kaushik, T. K. (2010e). Understanding Rural Ponds' Migratory Avian Diversity in Panchkula District in Haryana, India. Journal of Advanced Zoology, 31 (2): 117-123

Gupta, R. C. and Kaushik, T. K. (2011a). On the fast depleting trends of Cormorants in Kurukshetra wetlands in the last twenty five years. Journal of Experimental Zoology, India, 14 (1): 81-85

Gupta, R. C. and Kaushik, T. K. (2011b). On the fundamentals of natural history and present threats to Red-wattled Lapwing in Kurukshetra environs. Journal of Applied and Natural Science, 3(1): 62-67

Gupta, R. C., Kaushik, T.K. and Kumar, S.(2009). Analysis of winter migratory Wetland Birds in Karnal district in Haryana. Journal of Advanced Zoology, 30 (2): 104-117

Gupta, R. C., Kumar, S. and Kaushik, T. K. (2010c). Computation of route specific avi-faunal diversity in Morni Hills in Panchkula district in Haryana State in India. Journal of Advanced Zoology, 31 (1): 1-9

Gupta, R. C., Kaushik, T. K. and Kumar, S. (2010a). Evaluation of the extent of wetland birds in district Kaithal, Haryana, India. Journal of Applied and Natural Science, 2(1): 77-84

Gupta, R. C., Kaushik, T. K. and Kumar, S. (2010b). An account concerning arrival and departure time of few selected winter migratory birds in Haryana rural ponds. Environment Conservation Journal, 11(1\&2): 1-9

Kumar, A., Sati, J. P., Tak, P. C. and Alfred, J. R. B. (2005). Handbook on Indian Wetland Birds and their Conservation: i-xxvi; 1-468: Published by Director, Zool. Surv. India.

Manakadan, R. and Pittie, A. (2001). Standardized common and scientific names of the birds of indian subcontinent. Buceros, 6(1): i-ix, 1-38 